\title{
A DETERMINATION OF YIELD ON THE UNIVERSITY OF NEW BRUNSWICK WOODLOT
}

By W. M. Henderson, E. L. Brown, and M. Mackay, Senior Forestry Students, University of New Brunswick, Session 1943.44.

\section{INTRODUCTION}

$\mathrm{T}$

HE UNIVERSITY OF NEW BRUNSWICK, situated at Fredericton, N.B., owns a 3640-acre forest, part of a grant received by Royal Charter in 1800. In 1908 a Department of Forestry was established at the university. Forestry students of all four years receive a great deal of practical experience on this woodlot, traversing and mapping, locating and cutting out trails and roads, estimating timber volumes, selecting and marking trees for the annual cuts, scaling and other activities. Considerable research work is conducted by students along various lines such as insect counts, silvicultural projects, compilation of local volume tables, growth studies and yield predictions.

On Saturdays during the Senior year, the students work under the supervision of Prof. B. W. Flieger, doing extensive work in connection with topographic surveying. On Mondays they are instructed as to the various aspects of forest management by Dr. J. M. Gibson, the Dean of the School. With the help of records compiled by the students, and data collated from tabulated reports, Dr. Gibson is able to carry on an intensive management program on this woodlot. Selective logging and fuelwood operations are undertaken each winter. It is seldom that any part of this tract of land is clear-cut except in the case of scattered swamp types, in which the maple is cut and utilized for fuel. This fuelwood is cut by university employees and hauled to the university on tractor-drawn sleds. The procedure in regard to cutting and dispasing of logs is as follows--

(a) selling the stumpage on the area ,but only after all trees which are to be cut have been marked by the students.

(b) cutting of marked trees by university employees. The logs are sold to outside sources, having first been yarded to an accessible location by sleigh or truck.

\section{PURPose}

The study which is described in this report was made by Senior students during the fall and winter of the academic year 1943-44. On occasion it was found necessary to refer back to field work done by former students.

The purpose of this study was to predict the volume per acre which can be cut safely each year. The intention is to have the volume cut fully replaced by new growth over the thirty-year periad which has been adopted as the 
cutting cycle. In addition to this, it was decided to determine the size of the trees which should make up this volume. In conducting the study other information of interest in the management of the woodlot was accumulated.

\section{FIELD WORK}

1. During the winter of 1938.39 , a ten-per-cent continuous strip cruise was made of the entire woodlot. The part of the woodlot which was logged in the interim before 1943-1944 was cruised in a similar manner. While conducting these cruises diameters (breast height) were measured to the nearest inch. For checking the width of strip on the line, each three-man party was required to carry a bamboo pole $81 / 4$ feet in length. By using this pole frequently the caliper-man could be kept to the 33 -foot strip. The species measured were white pine, spruce, balsam, fir and hemlock.

2. Because of the limited period over which saw-logs have been selectively cut on the woodlot and statistical data on the cost collected, it was found necessary to take increment borings on the areas cut in a similar manner more than ten years ago. No records as to the volumes removed on these areas were available. These borings were not made in trees determined by mechanical sampling methods. Borings were made at breast height and to a depth great enough to show the last ten annual rings. Increment was measured to the nearest tenth of an inch, and diameters were taken outside the bark at breast height to the nearest inch. The species whose growth rates were studied were the same as those recorded during the various cruises. The results of these borings, by species, will be found plotted on the accompany. ing graphs.

Height growth was not studied as it is inherent in the volume tables.

No study of mortality was made and no information was available regarding it. Since selective logging methods are to be practised, it is assumed that most of the mortality will occur in the smaller and less important trees - that is, less important from the standpoint of volume. Also, part of the mortality due to wind-throw after cutting had occurred before the residual cruise was: made. It would be well to mention that, with a 10 per cent cruise and with the forest types and area involved, it would be sound to assume that the estimates have a twenty per cent standard error. With these factors in mind all volumes have been reduced by' twenty per cent to cover mortality together with any other inaccuracies in the estimates.

In all logging operations on the areas cut during the period 1939-1944, a complete scale (based on the N.B. Log Rule) was made of all logs removed. This work was done by licensed scalers and was used in connection with the original cruise to provide a check on the two cruises.

\section{InFORMATIOn AvaILABLE}

As a result of the studies made the following information was available for use in predicting growth and allowable cutting on the university woodlot. 
(1) 1939 cruise on 199 acres before cutting.

(2) 1944 cruise on 199 acres after cutting selectively for saw-logs over a five-winter period.

(3) Radial growth for the past ten years on residual trees in stands cut in a similar way over ten years ago.

(4) Scale sheets of the volumes cut on these areas.

\section{APPLICATION OF INFORMATION}

The residual stand as shown by the cut-over or residual cruise was projected ahead for a period of thirty years, using rate-of-growth data. This future volume, after considering the mortality reduction minus the present volume on the cut-over stands, was taken to be the volume per acre which can be removed every thirty years.

The size of the trees from which the volume could be taken was determined by interpolation (last column of the accompanying tables), working down from the greatest diameter present until the volume to be cut was reached.

The entire saw-log section on the woodlot was divided into thirty areas. By multiplying one of these areas by the volume per acre of expected cut, the allowable annual cut for the entire U.N.B. woodlot was indicated.

The scale sheets for the past five years showed an average cut per acre of $2.82 \mathrm{M}$ f.b.m. on this area. The volumes shown by the cruises were as follows-

Average volume per acre, original cruise .... 4.53 M f.b.m.

Average volume per acre, residual cruise .... $2.24 \mathrm{M}$ f.b.m.

Volume removed .............. $2.29 \mathrm{M}$ f.b.m.

Average cut based on scale ............. $2.82 \mathrm{M}$ f.b.m.

Comparison of the cruise and scale figures gives a difference of approximately twenty per cent. Some of this may be attributed to trees damaged in logging and lost through windthrow before the cruise of the residual stand was made. Some differences can also be expected in sampling any area of this size.

\section{Projection of Stands-Procedure.}

It was assumed that the growth rate for the thirty-year period between cuts would be the same as for the ten-year period following any cut. This may seem conservative in that the rate used has been influenced by the ad. justment required before release takes place following a cut. However, although release may come later, the rate will probably be held down by the rise in density of the stand toward the end of the thirty-year period. Thus we have compensating factors which will hold the rates at or near their conservative level.

The borings taken did not indicate any marked release after cutting. This is probably due to the fact that the stand was not heavily stocked before cutting and the trees measured did not happen to fall close to an area formerly occupied by a tree which was cut. 


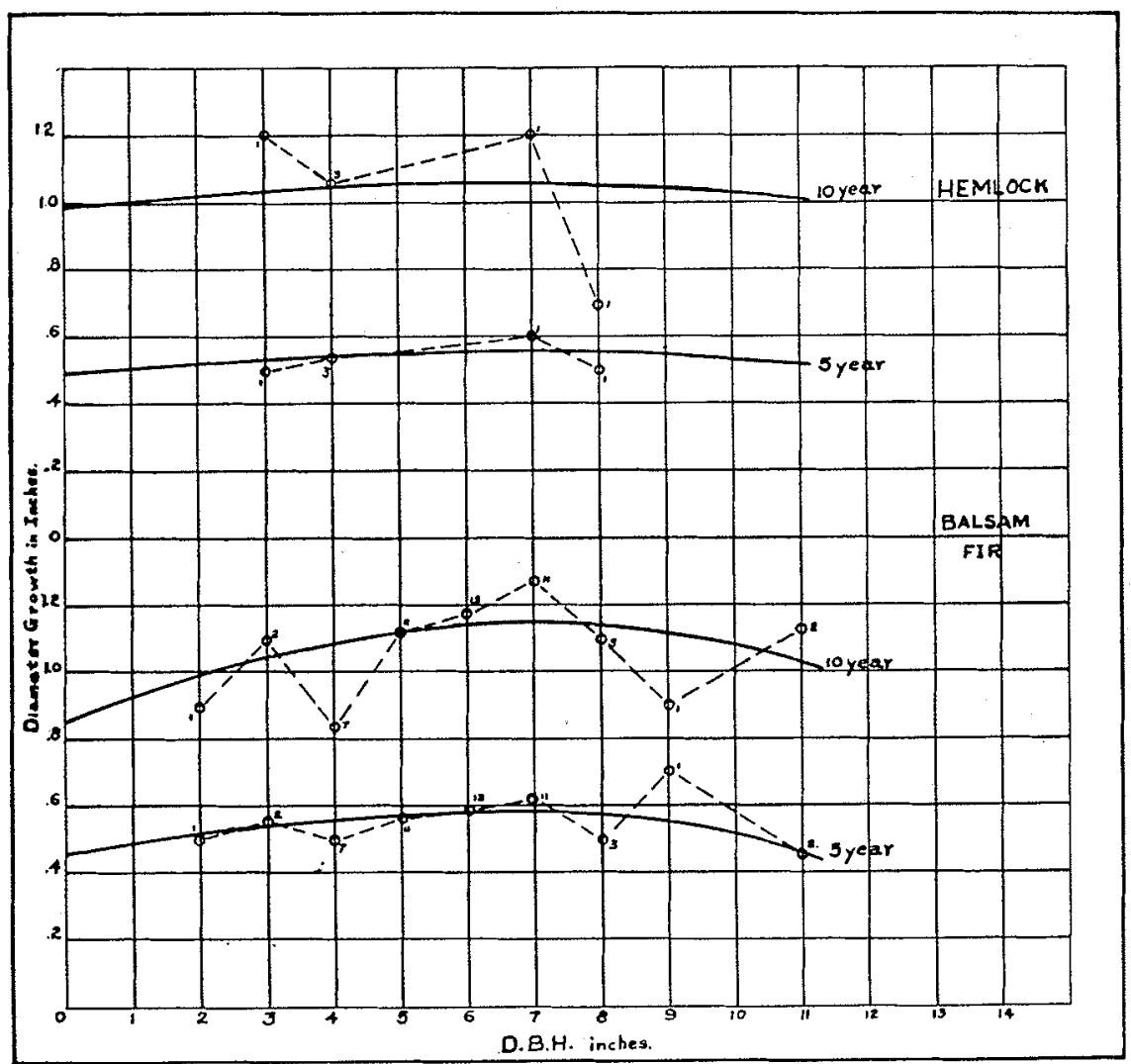

The conclusion, then, is that the growth rate depicted herein for stands after cutting does not differ appreciably from that of stands in which no disturbance has taken place. It is also evident from the graphs that for most species no correlation exists between diameter and growth rates.

Ir fir and hemlock the rate of growth is nearly constant for all diameters. The upward trend for the larger diameters of spruce may be disregarded since there have been very few large spruce left after cutting.

In white pine, however, we find a very noticeable rise in growth with the larger diameters. Because of this another method of projecting growth for this species was used. To quote Chapman and Demeritt-"on the whole it appears to be more accurate to use for future growth a rate which has been shown to be characteristic of given diameter classes in the past, than to assume a continuance into the future of the past rate of the trees measured".

The procedure used in predicting the future size of the pine trees might be best shown by an example: 





Referring to the graph-a six-inch tree shows a rate of 1.04 inches for the past ten years. Assuming this rate is applicable to the next ten-year period, we add 1.04 inches to six inches and get 7.04 inches. Now a 7.04 inch tree shows a rate of 1.12 inches for a ten-year period. Adding this we get 8.16 inches. This figure plus 1.21 inches (the ten-year growth on an 8.16-inch tree) gives 9.37 or 9.4 inches. Thus we are predicting that a six. inch pine tree will become a 9.4 inch tree after a period of thirty years.

Although this stand-projection is predicated on several assumptions which are not very reliable, it is the best that can be obtained from the information available and will provide a guide for future management.

\section{Determination of Trees to Be Cut}

Tables 1, 2, 3 and 4 show the volumes per acre which we recommend be removed in each cutting cycle. The last column in the tables shows the cumulative volumes from the maximum diameter class downward for any species immediately before the cut, These values together with the volume to be removed gave us a guide as to the lower diameter-limit to which the trees should be cut.

However, it is very important that the reader regard this lower diameterlimit as a guide only. In selective logging systems it is necessary to remove any trees which are deformed or not healthy regardless of size. Merchantable trees should be taken from dense groups and open areas should be allowed to develop toward normal stocking.

\section{Determination of Allowable Annual Cut}

Having outlined the compilation and development of the tables dealing with projection of stands by species under the head "Procedure", we are now in a position to apply the information so gained to the determination of the allowable annual cut ,based on perpetuation of a thirty'year cutting cycle on the U.N.B. woodlot.

Available information has been summarized in each of the four tables listed. After having made a 20 per cent deduction for such items as mortality based on the future volume per acre, the maximum allowable future volume per acre to be cut can be determined by subtracting the volume required in the residual from the above mentioned future volume per acre less twenty per cent.

Knowing the future volume per acre to be removed in each cut the lower diameter limit to which the trees can be cut can also be determined. It must be emphasized, however, that these diameter values will serve merely as a guide.

By adding together the future volumes per acre to be removed in the cut for each of the four species the total cut per acre can be determined.

It has been found through the work carried out each year on the woodlot that, of the actual 3640 acres belonging to the university, only 2300 acres have types suitable for saw-log production. Therefore, in determining the allowable annual cut we will use the figure of 2300 acres. 
Spruce (Table 1)

Future volume per acre ............. 2689 f.b.m. $20 \%$ deduction $\ldots \ldots \ldots \ldots \ldots \ldots \ldots \ldots \ldots \ldots . \ldots \ldots$ f.b.m.

Future volume after deduction .......... 2151 f.b.m. Future volume required in residual ........ 995 f.b.m.

Volume to be removed in cut .......... 1156 f.b.m.

Balsam Fir (Table 2)

Future volume per acre ............. 761 f.b.m. $20 \%$ deduction $\ldots \ldots \ldots \ldots \ldots \ldots \ldots \ldots \ldots \ldots$ f.b.m.

Future volume after deduction .......... 609 f.b.m. Future volume required in residual ....... 265 f.b.m.

Volume to be removed in cut ......... 344 f.b.m.

Hemlock (Table 3)

Future volume per acre ............. 566 f.b.m. $20 \%$ deduction $\ldots \ldots \ldots \ldots \ldots \ldots \ldots \ldots \ldots \ldots$ f.b.m.

Future volume after deduction .......... 453 f.b.m. Future volume required in residual ........ 215 f.b.m.

Volume to be removed in cut ......... 238 f.b.m.

White Pine (Table 4)

Future volume per acre ............. 1984 f.b.m. $20 \%$ deduction $\ldots \ldots \ldots \ldots \ldots \ldots \ldots \ldots \ldots$ f.b.m.

Future volume after deduction .......... 1587 f.b.m. Future volume required in residual ....... 764 f.b.m.

Volume to be removed in cut ........ 823 f.b.m.

Total cut per acre .............. 2561 f.b.m. Area available for saw-log operations ..... 2300 ac. Cutting cycle ................ 30 yrs.

Maximum allowable cut per year ........ 76.66 ac.

Cut per acre (above) ............. 2.56 M f.b.m.

The maximum allowable cut to perpetuate a thirty-year rotation on saw- $\log$ areas will be- $195 \mathrm{M}$ f.b.m.

Estimations of the maximum allowable annual cut have been made by students in past years by various other methods. They have all been between 150 and 200 f.b.m., which shows that the methods followed in this report are fairly reliable. 
From a study of the tables it would appear that the next cut would come from trees in the following size classes.

$\begin{array}{llll}\text { Spruce } \ldots \ldots \ldots \ldots & 12^{\prime \prime} & \text { D.B.H. plus } \\ \text { Fir } \ldots \ldots \ldots \ldots & 11^{\prime \prime} & \text { ". } \\ \text { Hemlock } \ldots \ldots \ldots & 12^{\prime \prime} & \text { ". } & \text { ". } \\ \text { White Pine } \ldots \ldots & 20^{\prime \prime} & \text { ". } & \end{array}$

The cumulative volumes in these size classes discounted $20 \%$ for unforeseen mortality will provide a cut of $2.77 \mathrm{M}$ f.b.m. per acre which checks reasonably well with the $2.56 \mathrm{M}$ f.b.m. already indicated.

Table I Spruce

(Diameters in inches, volumes in board feet)

\begin{tabular}{|c|c|c|c|c|c|c|c|}
\hline \multicolumn{3}{|c|}{ Residual Cruise } & \multirow{2}{*}{$\begin{array}{l}\text { Expd. } \\
\text { d. b. h. } \\
30 \text { yrs. }\end{array}$} & \multirow{2}{*}{$\begin{array}{l}\text { No. } \\
\text { Unit } \\
\text { Vol. }\end{array}$} & \multirow[b]{2}{*}{$\begin{array}{l}\text { Total } \\
\text { Vol. }\end{array}$} & \multirow{2}{*}{$\begin{array}{l}\text { Acc. Vol. } \\
30 \text { yrs. }\end{array}$} & \multirow{2}{*}{$\begin{array}{c}\text { Cumulative } \\
\text { Total Vol. } \\
\text { by diameter } \\
\text { ranges }\end{array}$} \\
\hline $\begin{array}{l}\text { Pres. } \\
\text { d. b.h. }\end{array}$ & No. & Vol. & & & & & \\
\hline 6 & 10.6 & 106 & 9 & $10.6 \times 30$ & 318 & 212 & 2689.5 \\
\hline 7 & 9.2 & 138 & 10 & $9.2 \times 40$ & 368 & 230 & 2371.5 \\
\hline 8 & 6.5 & 162.5 & 11 & $6.5 \times 65$ & 424 & 262 & 2003.5 \\
\hline 9 & 6.6 & 198 & 12 & $6.6 \times 90$ & 594 & 396 & $\overline{1579.5}$ \\
\hline 10 & 3.2 & 128 & 13 & $3.2 \times 120$ & 384 & 256 & 985.5 \\
\hline 11 & 2.0 & 130 & 14 & $2.0 \times 160$ & 320 & 190 & 601.5 \\
\hline 12 & 0.9 & 81 & 15 & $.9 \times 200$ & 180 & 99 & 281.5 \\
\hline 13 & 0.3 & 36 & 16 & $.3 \times 245$ & 73.5 & 37.5 & 101.5 \\
\hline \multirow[t]{2}{*}{14} & 0.1 & 16 & 17 & $.1 \times 280$ & 28 & 12 & 28. \\
\hline & & 995.5 & & & 2689.5 & 1694.5 & \\
\hline
\end{tabular}

Table II Balsam Fir

\begin{tabular}{|c|c|c|c|c|c|c|c|}
\hline \multicolumn{3}{|c|}{ Residual Cruise } & \multirow{2}{*}{$\begin{array}{l}\text { Expd. } \\
\text { d. b. h. } \\
30 \text { yrs. }\end{array}$} & \multirow[b]{2}{*}{ No. } & \multirow[b]{2}{*}{ Vol. } & \multirow{2}{*}{$\begin{array}{l}\text { Acc. Vol. } \\
30 \text { yrs. }\end{array}$} & \multirow{2}{*}{$\begin{array}{l}\text { Cumulative } \\
\text { Total Vol. } \\
\text { by diameter } \\
\text { ranges } \\
\end{array}$} \\
\hline $\begin{array}{l}\text { Pres. } \\
\text { d. b. h. }\end{array}$ & No. & Vol. & & & & & \\
\hline 6 & 11.5 & 80.5 & 9 & $11.5 \times 25$ & 287.5 & 207.0 & 761.5 \\
\hline 7 & 5.9 & 88.4 & 10 & $5.9 \times 40$ & 236.0 & 147.6 & 474.0 \\
\hline 8 & 2.1 & 52.4 & 11 & $2.1 \times 55$ & 115.5 & 63.1 & $\overline{238.0}$ \\
\hline 9 & 1.1 & 27.5 & 12 & $1.1 \times 75$ & 82.5 & 38.5 & 122.5 \\
\hline \multirow[t]{2}{*}{10} & 0.4 & 16.0 & 13 & $0.4 \times 100$ & 40.0 & 38.0 & 40.0 \\
\hline & & 264.8 & & & 761.5 & 474.2 & \\
\hline
\end{tabular}


Table III Hemlock

\begin{tabular}{|c|c|c|c|c|c|c|c|}
\hline \multicolumn{3}{|c|}{ Residual Cruise } & \multirow{2}{*}{$\begin{array}{l}\text { Expd. } \\
\text { d. b. h. } \\
30 \text { yrs. }\end{array}$} & \multirow[b]{2}{*}{ No. } & \multirow[b]{2}{*}{ Vol. } & \multirow[b]{2}{*}{$\begin{array}{c}\text { Acc. Vol. } \\
30 \text { yrs. }\end{array}$} & \multirow{2}{*}{$\begin{array}{c}\text { Cumulative } \\
\text { Total Vol. } \\
\text { by diameter } \\
\text { ranges }\end{array}$} \\
\hline $\begin{array}{l}\text { Pres. } \\
\text { d. b. h. }\end{array}$ & No. & Vol. & & & & & \\
\hline 6 & 2.9 & 29 & 9 & $2.9 \times 30$ & 87 & 58 & 566 \\
\hline 7 & 1.6 & 24 & 10 & $1.6 \times 40$ & 64 & 40 & 479 \\
\hline 8 & 1.2 & 30 & 11 & $1.2 \times 65$ & 78 & 48 & 415 \\
\hline 9 & 1.2 & 36 & 12 & $1.2 \times 90$ & 108 & 72 & $\overline{337}$ \\
\hline 10 & 0.8 & 32 & 13 & $0.8 \times 120$ & 96 & 64 & 229 \\
\hline 11 & 0.1 & 6.5 & 14 & $0.1 \times 160$ & 16 & 9.5 & 133 \\
\hline 12 & 0.2 & 18 & 15 & $0.2 \times 200$ & 40 & 22 & 117 \\
\hline 13 & 0.2 & 24 & 16 & $0.2 \times 245$ & 49 & 25 & 77 \\
\hline \multirow[t]{2}{*}{14} & 0.1 & 16 & 17 & $0.1 \times 280$ & 28 & 12 & 28 \\
\hline & & 215.5 & & & 566.0 & 350.5 & \\
\hline
\end{tabular}

Table IV White Pine

\begin{tabular}{cccccccc}
\hline \multicolumn{2}{c}{ Residual Cruise } & $\begin{array}{c}\text { Expd. } \\
\text { d. b. h. }\end{array}$ & & & & $\begin{array}{c}\text { Cumulative } \\
\text { Total Vol. }\end{array}$ \\
$\begin{array}{c}\text { Pres. } \\
\text { d. b. h. }\end{array}$ & No. & Vol. & 30 yrs. & No. & Vol. & $\begin{array}{c}\text { Acc. Vol. } \\
\text { 30 yrs. }\end{array}$ & $\begin{array}{c}\text { biameter } \\
\text { ranges }\end{array}$ \\
\hline 6 & .5 & 7.5 & 9 & $36 \times .5$ & 18 & 10.5 & 1984.1 \\
7 & .8 & 16 & 11 & $54 \times .8$ & 43.2 & 27.2 & 1966.1 \\
8 & 1.0 & 25 & 12 & $73 \times 1$ & 73 & 48 & 1922.9 \\
9 & 1.4 & 50 & 13 & $92 \times 1.4$ & 128.8 & 86.8 & 1849.9 \\
10 & .7 & 31.5 & 15 & $125 \times .7$ & 87.5 & 56 & 1721.1 \\
11 & .7 & 38 & 16 & $156 \times .7$ & 109.2 & 67.2 & 1633.6 \\
12 & 1.4 & 102 & 17 & $188 \times 1.4$ & 263.2 & 158.2 & 1524.4 \\
13 & .8 & 74 & 18 & $227 \times .8$ & 181.6 & 109.6 & 1261.2 \\
14 & .5 & 55.0 & 20 & $277 \times .5$ & 138.5 & 83.5 & 1079.6 \\
15 & .7 & 87 & 21 & $330 \times .7$ & 231.0 & 133 & 941.1 \\
16 & .4 & 62 & 23 & $408 \times .4$ & 163.2 & 99.2 & 710.1 \\
17 & .5 & 94 & 24 & $475 \times .5$ & 237.5 & 145 & 546.9 \\
18 & .2 & 45 & 25 & $542 \times .2$ & 108.4 & 65.4 & 309.4 \\
19 & .2 & 49.0 & 27 & $645 \times .2$ & 129.0 & 80 & 201.0 \\
20 & .1 & 28 & 28 & $720 \times .1$ & 72.0 & 43.5 & 72.0 \\
\hline & & 764.0 & & & 1984.1 & 1213.1 & \\
\hline
\end{tabular}

